\title{
Children Involvement in Terrorism Activities: Perpetrator or Victim? (A Study on the Circle of Violence)
}

\author{
Wawan Edi Prastiyo*, I Ketut Rai Setiabudhi** \\ DOI: https://doi.org/10.22304/pjih.v8n2.a3
}

Submitted: February 5, 2021 | Accepted: June 17, 2021

\begin{abstract}
Terrorism is an extraordinary crime since it violates human rights. However, it will be different if children commit it. The legal approach is not necessarily taken against children who become terrorists. The problem of children's involvement in terrorist activities does not end there. Another important issue that must also be considered is children of terrorist parents. They must be rescued from a violent social environment. In this study, we will discuss the position of children as victims in the cycle of violence of terrorism and criminal policies in overcoming the involvement of children in terrorism activities. This research is normative legal research that examines the availability of provisions regulating the involvement of children in terrorism activities. Legal materials come from primary and secondary legal materials that are collected through literature study. Children who become terrorists are actually victims indoctrinated to commit terrorism which is believed as a struggle. Therefore, a human rights approach is needed to provide child protection. The criminal policy in tackling the involvement of children in terrorism activities is carried out by regulating the rehabilitation of radicalized children who are perpetrators and the placement of children whose parents are members of terrorism networks in a safe place.
\end{abstract}

Keywords: children, circle of violence, terrorism.

\section{Keterlibatan Anak dalam Kegiatan Terorisme: Sebagai Pelaku atau Justru menjadi Korban? (Suatu Kajian dalam Lingkaran Kekerasan)}

\begin{abstract}
Abstrak
Terorisme adalah kejahatan yang luar biasa dan melanggar hak asasi manusia, namun hal ini akan berbeda apabila dilakukan oleh anak. Pendekatan hukum tidak serta merta dilakukan terhadap anak yang menjadi teroris. Permasalahan tentang keterlibatan anak dalam kegiatan terorisme bukan hanya sampai di sana. Permasalahan penting lainnya yang juga harus diperhatikan adalah anak yang berada pada lingkungan orang tua yang menjadi

PADJADJARAN Journal of Law Volume 8 Number 2 Year 2021 [ISSN 2460-1543] [e-ISSN 2442-9325]

* Doctoral Student of the Faculty of Law, Universitas Udayana, Jl. Pulau Bali 1 Denpasar Bali, S.H., M.H. (Universitas Udayana), weprojo@gmail.com.

** Lecturer of the Faculty of Law, Universitas Udayana, Jl. Pulau Bali 1 Denpasar Bali, Prof., Dr., S.H., M.H. (Universitas Udayana), raisetiabudhi_fhunud@yahoo.com.
\end{abstract}


teroris. Anak harus diselamatkan dari lingkungan sosial yang diwarnai dengan kekerasan. Dalam penelitian ini, akan dibahas mengenai posisi anak sebagai korban dalam lingkaran kekerasan dan kebijakan kriminal dalam penanggulangan keterlibatan anak dalam kegiatan terorisme. Penelitian ini adalah penelitian yuridis normatif yang membahas tentang ketersediaan ketentuan yang mengatur mengenai keterlibatan anak dalam kegiatan terorisme. Bahan hukum berasal dari bahan hukum primer dan juga bahan hukum sekunder yang dikumpulkan dengan studi kepustakaan. Anak yang menjadi teroris sesungguhnya merupakan korban di mana anak tersebut telah terdoktrin untuk melakukan terorisme yang diyakini sebagai suatu perjuangan. Oleh sebab itu, diperlukan pendekatan hak asasi manusia yang dapat memberikan perlindungan anak. Kebijakan kriminal dalam penanggulangan keterlibatan anak dalam kegiatan terorisme dilakukan dengan regulasi tentang rehabilitasi bagi anak yang menjadi pelaku dan telah terpapar paham radikalisme dan penempatan anak yang orang tuanya menjadi anggota jaringan terorisme di tempat yang aman.

Kata Kunci: anak, lingkaran kekerasan, terorisme.

\section{A. Introduction}

Terrorism is an organized transnational crime ${ }^{1}$ that has caught the attention of developed and developing countries and because terror attacks have evolved using weapons of mass destruction in the form of chemical, biological, radioactive, and nuclear weapons. ${ }^{2}$ Article 1 number 2 of Law of the Republic of Indonesia Number 5 of 2018 on Amendments to Law Number 15 of 2003 on Stipulation of Government Regulations in Lieu of Law Number 1 of 2002 On the Eradication of Criminal Acts of Terrorism into Law (hereinafter referred to as Law on the Eradication of Criminal Acts of Terrorism 2018) reads as follows. ${ }^{3}$

"Terrorism is an act that uses violence or threats of violence that create an atmosphere of terror or widespread fear, which can cause mass victims, and/or cause damage or destruction to a vital strategic object, the environment, public facilities, or international facilities with motives of ideology, politics, or security disturbances."

1 See General Assembly Resolution 55/25 of 15 November 2000 United Nations Convention against Transnational Organized Crime.

2 Runturambi, Arthur Josias Simon, and Sidratahta Mukhtar, "Strategi Pencegahan Serangan Teroris di Indonesia Menggunakan Weapons Mass Destruction (WMD) oleh POLRI, BNPT, BAPETEN, TNI, BNPB dan KEMENPERIN", Journal of Terrorism Studies, Vol. 2, No. 1, 2020, p. 115.

3 Article 1 Number 2 of Law of the Republic of Indonesia Number 5 of 2018 on the Amendments to Law Number 15 of 2003 on the Stipulation of Government Regulations in Lieu of Law Number 1 of 2002 on the Eradication of Criminal Acts of Terrorism into Law. 
In recent years, acts of terrorism involve childre ${ }^{4}$ as perpetrators of terrorism. Based on data from the Asian Muslim Action Network, in 2015, it was recorded that 3,500 young people in western countries were recruited by ISIS through social media. In 2017, as many as 1,500 children underwent military training at the Islamic State of Iraq and Syria (ISIS) military training camps. The suicide bombings in Sidoarjo and Surabaya, East Java, in 2018 involved three women and eleven children. ${ }^{5}$ Apart from using children as executors of suicide bombings, children are also involved as informants in terrorism activities. The Child Rights International Network says, "children are also used by States for counter-terrorism operations, particularly as spies and informants." 6

The Assistant Deputy for Child Protection in Dealing with Law and Stigmatization, the Ministry of Women Empowerment and Child Protection of the Republic of Indonesia, states that the recruitment of terrorism networks is carried out through social media. Several factors cause children to become involved in radicalism and acts of terrorism. The first comes from a close family, even from a nuclear family. "There are parents or other family members who teach radicalism and terrorism to children. Another factor that causes children to be involved in terrorism activities is the environment, such as friends and neighbors who teach radicalism and terrorism to children. The last factor is the root cause of radicalism and terrorism, poverty." 7

Young people experiencing a transitional period of identity crisis cause them to have high vulnerability to the influence and calls of radicalism in the name of religion. Cognitive opening occurs during this transition period. A micro-sociological process that brings them closer to acceptance of new, more radical ideas. This can be proven by statistical data, which shows that young people are the majority in terrorists, suicide bombers and jihadists in Syria. ${ }^{8}$ Children are a unique group in terms of crime. Children with unstable emotional development and minimal life experience have an inability to process information. They are unable to make

4 See Article 1 Convention on the Rights of the Child:

"For the purposes of the present Convention, a child means every human being below the age of eighteen years unless under the law applicable to the child, majority is attained earlier".

5 Jobpie Sugiharto, "Jumlah Perempuan Terlibat Terorisme Meningkat, Lihat Angkanya", https://nasional.tempo.co/read/1276689/jumlah-perempuan-terlibat-terorisme-meningkat-lihatangkanya/full\&view=ok., accessed on February 2021.

6 The Child Rights International Network, Caught in the Crossfire? An International Survey of Anti-Terrorism Legislation and its Impact on Children, London: CRIN Press, 2018, p. 25.

7 Irfan Kamil, "Kementerian PPPA Sebut Media Sosial Kini Dipakai untuk Rekrut Anak dalam Aksi Terorisme", https://nasional.kompas.com/read/2020/07/08/18160401/kementerian-pppa-sebut-media-sosial-kinidipakai-untuk-rekrut-anak-dalam?page=all accessed on February 2021.

8 Rindha Widyaningsih, Sumiyem Sumiyem, and Kuntarto Kuntarto, "Kerentanan Radikalisme Agama di Kalangan Anak Muda", Prosiding, Vol. 7, No. 1, 2017, p. 1559. 
decisions and more impulsive. Therefore, they can be manipulated, victimized, and recruited by terrorist organizations. ${ }^{9}$

Indeed, children who are involved in terrorism activities are caused by psychological condition that make easy to be manipulated, the criminal justice system still imposes imprisonment on children who are perpetrators. The issue of children's involvement in terrorism activities does not only extend to active involvement but also to the conditions that occur in children with terrorist parents. According to the National Counterterrorism Agency, in 2018, about 500 parents had been terminated and designated as prisoners. Consequently, it was estimated that there are 1,800 children whom the government has not handled yet. The children experience labeling, stigmatization, discrimination, bullying that requires handling, coaching, assistance, and recovery. ${ }^{10}$

This condition causes the children to be in an environment of violence, shown by their parents, as well as violence obtained from the social environment that rejects the presence of these children. The "cycle of violence" hypothesis suggests that a history of violence in childhood turns survivors into actors of violence in later years. This means that violence that occurs against children tends to be followed by other violence. This is in line with what Hasanah and Raharjo states that children who experience violence in their past have the potential to commit violent acts (perpetrators) when they grow up. ${ }^{11}$ This study reveals that victims who are rejected by their environment also tend to develop violent criminal behavior in the future. ${ }^{12}$ Violence has nothing to do with genetics but is acquired through social learning. Burgess and Akers say that both deviant behavior and appropriate behavior are developed through an individual learning process, with determinants being the direction and influence of individual behavior. ${ }^{13}$ Children who are in a terrorist environment and are stigmatized by their environment tend to become perpetrators of terrorism in the future and become perpetrators of other acts of violence. In this research, we will discuss the position of children as victims in the

\footnotetext{
$9 \quad$ United Nations Interregional Crime and Justice Research Institute, "Promoting Juvenile Justice Standards to Prevent the Recruitment by Violent http://www.unicri.it/topics/counter_terrorism/juvenile_diversion, accessed on February 2021.

10 Kautsar Widya Prabowo, "1.800 Anak Pelaku Terorisme Tidak Terjamah Pemerintah", https://www.medcom.id/nasional/hukum/IKY6ZoWN-1-800-anak-pelaku-terorisme-tidak-terjamahpemerintah. accessed on February 2021.

11 Uswatun Hasanah and Santoso Tri Raharjo, "Penanganan Kekerasan Anak Berbasis Masyarakat", Share: Social Work Journal, Vol. 6, No. 1, 2016, p. 82.

12 Cathy S. Widom and Michael G. Maxfield, An Update on the "Cycle of Violence", Washington: U.S. Department of Justice, 2011, p. 1.

13 Bryanna Fox, "It's Nature and Nurture: Integrating Biology and Genetics into the Social Learning Theory of Criminal Behaviour", Journal of Criminal Justice, Vol. 49, No. 1, 2017, pp. 22-31.
} 
cycle of violence and criminal policies in overcoming the involvement of children in terrorism activities.

\section{B. Children as Victims in A Cycle of Violence of Terrorism}

Actions of violence with terror appear along with the level of human civilization. This can be traced from the writings of Xenophon (431-350) on the Roman violence in Spartacus (73 CE) and the history of Emperor Tiberius (14-37 BCE) who got rid of, threw away, seized property, and punished his political opponents. ${ }^{14}$ Although the practice of terror began in BCE, the terms terror and terrorism only appeared in scientific vocabulary since the $18^{\text {th }}$ Century. In its development, acts of terrorism are related to the understanding of religious teachings. This condition indicates a change in value occurring in society. Patirim Sorokin argues that the development of law and other social phenomena is adjusted to the specific stages that each society goes through. Society develops according to certain values that are currently prominent in said society. These values are ideational (i.e. absolute truth as revealed by Almighty God), sensate (i.e. values based on experience), and idealistic (which is a mixed category). Laws and other socio-cultural phenomena are formed in accordance with the forms of values that are currently prevailing in society. ${ }^{15}$

Terrorism is a crime against humanity and a serious threat to the sovereignty of every country. It is an international crime that poses a danger to security, world peace, and people's welfare. It is necessary to eradicate it in a planned and sustainable manner so that the human rights of many people can be protected and upheld. ${ }^{16}$ Terrorism is not only a crime that threatens and destroys the security and integrity of a nation and state but also destroys the order and peace of the international community. Global harmonization can be torn apart because countries suspect and criticize each other due to the possibility of suspects or perpetrators. ${ }^{17}$ Terrorism, seen as violating and oppressing human rights, undergoes a conflict if the perpetrator is a child. ${ }^{18}$ On the one hand, children who are perpetrators of terrorism are criminals. On the other hand, those children are victims of wrong treatment, care, and social environment. According to Kartono, a child is a normal human condition of being young and very unstable in spirit, still determining an identity, so it is very easy to be affected by the environment. ${ }^{19}$

\footnotetext{
14 Dikdik M Arief Mansur and Elisatris Gultom, Cyber Law Aspek Hukum Teknologi Informasi, Bandung: Refika Aditama, 2005, p. 48.

15 Soerjono Soekanto, Pokok-pokok Sosiologi Hukum, Jakarta: PT Raja Grafindo Persada, 2009, p. 107.

16 Riad Tia Wardana and Dahlan Ali, "Upaya Pencegahan Tindak Pidana Terorisme oleh Direktorat Intelijen Keamanan (Suatu Penelitian di Kepolisian Daerah Aceh)", Jurnal IImiah Mahasiswa Bidang Hukum Pidana, Vol. 3, No. 3, 2019, p. 488.

17 Abdul Wahid (et.al.), Kejahatan Terorisme Perspektif Agama, HAM dan Hukum, Bandung: Refika Aditama, 2004, p. 13.

18 Agus Sugiarto, "Tinjauan Yuridis Anak sebagai Pelaku Tindak Pidana Terorisme tentang Sistem Peradilan Pidana Anak", Jurnal Syntax Transformation, Vol. 1, No. 9, 2020, p. 570.

19 Kartini Kartono, Gangguan-gangguan Psikhis, Bandung: Sinar Baru, 1981, p. 187.
} 
Even though a child's mental condition is not yet capable of making a decision, children involved in terrorism activities are still punished according to the provisions of laws and regulations even though the punishment is not the same as that of adults. According to Article 3 of Law of the Republic of Indonesia Number 11 of 2012 on the Juvenile Criminal Justice System "Every child in a criminal justice process has the right: not to be sentenced to death or life imprisonment". Furthermore, in paragraph 79 (2), the punishment for restricting freedom imposed on children is a maximum of $1 / 2$ (half) of the maximum imprisonment imposed on adults. The threat of imprisonment is a very dominant formula in the Indonesian Criminal Code since the past. The formulation of the imperative imprisonment threat in Indonesia is a legacy from the classical school of thought, which stipulates a sentence with a definite sentence. ${ }^{20}$ This has resulted in this type of imprisonment being the most sanctioned punishment by judges in Indonesia, including against criminal acts of terrorism. Imposition of imprisonment for children involved in terrorism activities can be seen in the Klaten District Court Decision Number: 19/Pid.Sus/2011/PN.KIt, in which children who are perpetrators of terrorism are sentenced to two years. This condition certainly collides with the perspective of the best interests of children, in which children who become terrorists are victims of radicalization. Children as perpetrators of criminal acts of terrorism cannot be considered as perpetrators of crime. They are victims of crime, victims of terrorist networks, victims of doctrine, exploitation of ideas and propaganda from the invitation of their parents or adults around them so they must be specially protected. ${ }^{21}$

Imprisonment on children who are involved in terrorism activities will certainly face new problems. Penitentiaries are a conducive vehicle for the spread of radical ideology, recruitment of members, and the development of extremist groups. ${ }^{22}$ The Institute for Analysis of Conflict's (2016) report on radicalization in prisons states that general prisoners can be recruited to become members of terrorist group networks in three different ways. First, through proficiency in fights between prisoners; second, through the desire for better food; and third, through close community appeal. As a result, 18 former general convicts were involved in

20 Barda Nawawi Arief, Kebijakan Legislatif dalam Penanggulangan Kejahatan dengan Pidana Penjara, Semarang: Universitas Diponegoro, 1994, pp. 201-202.

21 Ahmad Mahyani, "Perlindungan Hukum Anak sebagai Pelaku Terorisme", Jurnal Hukum Magnum Opus, Vol. 2, No. 1, 2019, p. 47.

22 Saifudin Asrori, "Prisonisasi dan Penyebaran Ideologi Radikal di Lembaga Pemasyarakat", Mimbar Agama Budaya, Vol. 36, No. 1, 2019, pp. 39-56. 
terrorism cases in Indonesia between 2010-2016. ${ }^{23}$ This condition illustrates that prisoners tend to become terrorists if they associate with terrorist convicts in prisons. The radicalization was carried out by terrorist convicts against other prisoners in social institutions. Within minimum security prisons, extremist terrorism convicts can freely recruit other convicts to become sympathizers. They can maintain contact with the outside world to engage in subtle activities that undermine Indonesia's security without the prison officials knowing. ${ }^{24}$ Children who already have a history of being exposed to radicalism will be increasingly poisoned while in prisons, especially for children who commit terrorism before the age of 18 but are serving a prison sentence when they are over 18 years of age.

According to Mahyani, an easily brainwashed son of the perpetrator of terrorism is actually a victim of recruitment and indoctrination with the concept of jihad that goes too far. The promise of heaven without explaining the true meaning of jihad lures children looking for self-identity. They do not understand the target of jihad, conditions that must be met and under what conditions the jihad orders are carried out. Finally, the victims are the children themselves and the innocent society. ${ }^{25}$ The existence of child terrorists is not because children voluntarily become terrorists, but because adults try to exploit them. As explained above, terror groups exploit children in two ways. (1) By brainwashing, namely instilling radical ideologies to children who are experiencing an identity crisis. 2) By carrying out forced recruitment in which children are kidnapped and intimidated by members of terrorist groups. Children are not only instilled with radical ideals but also armed and forced to commit acts of violence against others. ${ }^{26}$

Children of a family involved in terrorist activities are easier to join terrorist networks. This condition does not occur because of evil behavior obtained from inheritance, but because of social learning. The acts of terror on May 13, 2018, at the Catholic Church "Santa Maria Tak Bercela" in Ngagel, Surabaya, East Java were carried out by brothers. The bomb attack that occurred at GKI Diponegoro was carried out by a woman with her two children. ${ }^{27}$ This condition shows that radical understanding can grow in the family environment, it is disseminated and taught to their own children. Basically, terrorism is not hereditary. However, the fact that a

\footnotetext{
23 Laode Arham, "Budaya Penjara, Subkultur Terorisme dan Radikalisasi: Perspektif Kriminologi Budaya", Journal of Terrorism Studies, Vol. 2, No. 4, 2021, p. 3.

24 Rini, Dian Eko, and Teguh Kurniawan, "Deradikalisasi Teroris melalui Lapas Supermaksimum Security dari Perspektif Implementasi Kebijakan", Publikauma: Jurnal Administrasi Publik Universitas Medan Area, Vol. 7, No. 2, 2019, p. 43.

25 Ahmad Mahyani, op.cit., p. 50.

26 Saraswati and Elsafira Maghfiroti Resyanta, "Pemprofilan Pelaku Teroris Anak", Etnoreflika: Jurnal Sosial dan Budaya, Vol. 9, No. 2, 2020, p. 137.

27 Antara, "Kesaksian Tragedi Bom Gereja Katolik Santa Maria Tak Bercela", https://www.cnnindonesia.com/nasional/20180514085029-20-297935/kesaksian-tragedi-bom-gerejakatolik-santa-maria-tak-bercela, accessed on May 2021.
} 
child terrorist occurs due to influence by various factors is a certainty. ${ }^{28}$ Sutherland in the Deferential Association Theory assumes that children's behavior is not inherited from their parents. Deviant behavior carried out by children comes from association through the process of interaction and communication learned in a group. In the process, the child learns the techniques for committing crimes and the reasons that support the evil behavior. ${ }^{29}$

The Differential Association theory ${ }^{30}$ formulates a person's learning process to become a criminal as (1) evil behavior is learned. Negatively, criminal behavior is not inherited, people who are not proficient or have no skills to commit crimes do not show criminal behavior. (2) Bad behavior is learned in interaction through a communication process. This communication is not only in verbal form but also includes body language or "the communication of gesture". The most important part of learning evil behavior occurs in the interpersonal relationships of close groups. (3) Negatively, impersonal communication agents, such as films and newspapers, play a relatively insignificant part in learning evil behavior. (4) Learning evil behavior includes (a) techniques to commit crimes, which are sometimes complex, sometimes simple; (b) specific directions of motivation, encouragement, rationalization, and attitudes. (5) Certain directions of motivation and drive are learned from the definition of the rule of law as pleasant or unpleasant. In society, an individual is surrounded by people who invariably define the rule of law as rules to be obeyed, while elsewhere he is surrounded by people who define the advantages of breaking the law. (6) The main principle of the Differential Association is that someone becomes a criminal due to the benefit of breaking the law. (7) Unequal associations may vary in duration, frequency, priority and intensity. (8) The process of learning criminal behavior with criminal groups and anti-criminal groups is about the ways and mechanisms that are mutually involved with one another. (9) Criminal behavior is a general expression of common values and needs. However, it cannot explain evil behavior. It only shows the equation of need and value. Based on The Differential Association theory, children who become perpetrators of terrorism are not caused by genetic factors inherited from their terrorist parents. These children learn radicalism from patterns of social interaction with their parents.

Children who are victims of violence with unresolved feelings of anger, hatred and sadness tend to become perpetrators of terrorism in the future. In 2012, there

28 Josua Hamonangan Bangun, "Internalisasi Kesadaran Berbangsa Bernegara Anak Teroris", JUSTITIA: Jurnal IImu Hukum dan Humaniora, Vol. 7, No. 3, 2020, p. 617.

29 Deny Guntara, "Tinjauan Kriminologi terhadap Pelaku Tindak Pidana Terorisme di Indonesia dalam Perspektif Teori Differential Association", Justisi Jurnal Ilmu Hukum, Vol. 3, No. 1, 2018, p. 108.

30 Mohammad Ali, Psikologi Remaja, Jakarta: Bumi Askara, 2012, p. 9. 
was a shooting at the Solo Police Station by AB's stepson. What the child did was a form of revenge against the police for his father's arrest. The children of the perpetrators of terrorism are certainly obtained from cultivating the ideology of their parents, which involved them in radicalist and terrorist movements. The child was raised by his stepfather and was involved in several acts of terrorism committed by his stepfather. Perpetrators have been taught to use weapons since childhood. Children in a radicalism//terrorism network are still allowed to grow and develop in their environment and network, which is very dangerous. ${ }^{31}$ Gallimore ${ }^{32}$ finds the following research results by conducting research on offenders' personalities. It is evidenced that unresolved personal trauma in the past resulted in narcissistic and paranoid leaders who used historical group trauma, or selected trauma, to mobilize the masses to engage in murder. People who have been victims are in a cycle of violence by taking revenge for the psychological wounds they have experienced. The primary motive for the American terrorists examined in this study was anger at the injustice they experienced and a desire for revenge. ${ }^{33}$

Gelles Richard J. notes several factors that cause violence against children, and one of them is the pattern of inherited violence between generations (intergenerational transmission of violence). ${ }^{34}$ Adults who have been victims of violence when they are children tend to do the same to their own children. ${ }^{35}$ Children of a terrorist family do not have it easy. Even though the child is not actively involved in terrorist activities carried out by the parents, the child tends to experience psychological violence from the environment. Maknunah finds that children whose families are involved in terrorism networks get stigma from their neighborhoods and schools for cases that have happened to their parents. A child in Jakarta who, after his parents are arrested, experiences bullying and negative stigma from his friends at school, making him refuse to go to school. ${ }^{36}$

\section{Criminal Policy in Combating the Involvement of Children in Terrorism Activities}

The rapid development of terrorism makes it no longer derived from national scale. Terrorism has transformed into a transnational crime that has networks and resources. It means that handling terrorism can no longer rely solely on a state security approach. ${ }^{37}$ Sutton explains that, based on the focus of the criminology intervention, the criminological classification divides prevention with social and

\footnotetext{
31 Khariroh Maknunah, Penanganan Anak dalam Tindak Pidana Terorisme, Jakarta: Csave, 2016, p. 5.

32 Timothy Gallimore, Unresolved Trauma: Fuel for the Cycle of Violence and Terrorism, Washington DC: Greenwood Publishing Group, 2004, p. 67.

Ibid.

$34 \quad$ Yohanes Servasius Lon and Fransiska Widyawati, "Lingkaran Kekerasan Terhadap Anak dalam Masyarakat Manggarai", Jurnal Pendidikan dan Kebudayaan Missio, Vol. 9, No. 1, 2017, p. 12.

Ibid.

Khariroh Maknunah, op.cit., p. 5.

Markus H. Simarmata, "Pentingnya Prinsip-Prinsip Hukum Humaniter dalam Undang-Undang Tindak Pidana Terorisme", Jurnal Legislasi Indonesia, Vol. 15, No. 2, 2018, p. 120.
} 
environmental approaches. Social deterrence tries to reduce the likelihood that individuals or groups will include crime in their behavioral repertoire by strengthening informal relationships (e.g., close and extended family, environmental networks, peer groups) and by institution (e.g., in education, employment, culture, and sport) to obey the law. ${ }^{38}$

Acts of terrorism involving children must be studied further. The criminal policy to tackle the involvement of children in terrorism activities needs to be carried out with a human rights approach. Children's rights are human rights; therefore, the state places a legal obligation on the government and everyone to protect children's rights. Every child has the right to protection. Protection means all the efforts made to prevent, rehabilitate, and empower children who experience child exploitation and neglect. It is done to ensure the child's survival and development physically, mentally, and socially in a reasonable manner. ${ }^{39}$

The involvement of children in terrorist activities constitutes the exploitation and mistreatment of children. Children should get an education and inculcate good values, not be colored by violence. They must be protected from various forms of violence and mistreatment. Child protection is an international issue in the United Nations (UN) convention on children's rights. ${ }^{40}$ In addition, several international legal instruments also regulate child protection, such as The UN Guidelines for the prevention of juvenile Delinquency (The Riyadh Guidelines), The UN Standard Minimum Rules for the Administration of Juvenile Justice (The Beijing Rules) and The UN Rules for the Protection of Juvenile Deprived of Their Liberty. ${ }^{41}$ The standard minimum rules of the United Nations regarding the administration of courts for children (The Beijing Rules), in principle, are that every child who is in conflict with the law has the right to receive equal treatment. The implementation of juvenile justice must be effective, fair and humane without distinction and discrimination. ${ }^{42}$

Legal instruments that provide child protection place the principle of the best interests of the child as a fundamental principle. The best interest of the Convention on the Rights of the Child is an important principle in child protection.

\footnotetext{
38 Adam Sutton (et.al.), Crime Prevention Principles, Perspectives, and Practices, New York: Cambridge University Press, 2008, p. 22.

39 Arif Gosita, Masalah Perlindungan Anak, Jakarta: Akademi Presindo, 2001, p. 52.

40 Convention on the Rights of the Child 1989. The Convention on the Rights of the Child has been ratified by more than 191 countries.

41 Maidin Gultom, Perlindungan Hukum terhadap Anak dalam Sistem Peradilan Pidana Anak Indonesia, Bandung: Refika Aditama, 2014, p. 51.

42 Marlina, Peradilan, Pidana Anak di Indonesia, Bandung: Refika Aditama, 2012, p. 49.
} 
This principle is legitimized in the Convention on the Rights of the Child, November 20, 1989. Article 3 point 1 states: ${ }^{43}$

"In all actions on children, whether undertaken by public or private social welfare institutions, courts of law, administrative authorities or legislative bodies, the best interests of the children shall be a primary consideration."

The principle of the best interest of the child reminds all child protection providers that the considerations in decision making must be related to the future of the child, not based on adult standards, or centered on the interests of adults. What is considered good by adults is not necessarily good according to the measure of children's interests. It may be that the adult means to provide assistance and help, but what actually happens is the destruction of the child's future. ${ }^{44}$

In carrying out a global commitment, the United Nations Office on Drugs and Crime (hereinafter referred to as UNODC) issues several policy agendas that can serve as guidelines for countries to save children from terrorism activities, for children who have been directly involved, who tend to participate in terrorist activities and those who have not been exposed to radicalism. In the field of violence against children and justice for children, UNODC's work is based on three pillars, which are mutually reinforcing. First is data collection, research and analytical work that examines crimes in the implementation of the juvenile criminal justice system. These activities also include developing standards and indicators to measure national crimes and a criminal justice information system related to violence against children. Second, normative work: UNODC as the Secretariat of the Commission for the Prevention of Crime and Criminal Justice and the United Nations Crime Congress assists Member States in developing United Nations standards and norms on violence against children and justice for children. Third, operational work. In this operational work, UNODC carries out technical cooperation projects with various parties to prevent the involvement of children and youth in crime, strengthen the juvenile justice system, and promote the rehabilitation as well as reintegration of children in connection with the law to end violence against children and improve justice for the child system. ${ }^{45}$

Child protection is based on the understanding that the child is also involved as the perpetrator of terrorism. The child is still seen as a victim, at least a victim of mistreatment by parents or their social environment. Child protection in Indonesia is based on international legal instruments. This is a consequence of Indonesia's participation as a member of the United Nations, which has ratified and adopted

43 Article 3 point 1 of the Convention on the Rights of the Child.

44 M. Nasir Djamil, Anak Bukan untuk Dihukum, Jakarta: Sinar Grafika, 2013, p. 30.

45 United Nations Office on Drugs and Crime, "Global Programme to End Violence Against Children", https://www.unodc.org/unodc/en/justice-and-prison-reform/global-programme-to-end-violence-against-

children_programme-details.html, accessed on February 2021. 
the principles in the Convention on the Rights of the Child, based on Presidential Decree No. 36 of 1990. Child protection is carried out with various considerations as a basis for philosophical, ethical, and juridical considerations. The philosophical basis for the concept of child protection in Indonesia is Pancasila. Pancasila is the basic norm which is the source of state law. Pancasila is the basis of activities in various fields of family, community, state, and national life. Pancasila is the basis for the philosophy of implementing child protection. The ethical basis for implementing child protection must be in accordance with the relevant professional ethics to prevent deviant behavior in the exercise of authority, power, and strength in child protection. The juridical basis for implementing child protection must be based on the 1945 Constitution and various other applicable laws and regulations. The application of juridical basis must be integrative, namely the integrated application of laws and regulations from various related fields of law. ${ }^{46}$

The criminal policy in tackling children's involvement in terrorism activities has been seen in the amendment to the regulation on the prohibition of terrorism in Indonesia, namely the Law on the Eradication of Criminal Acts of Terrorism 2018. Article 16A states that "Every person who commits a criminal act of terrorism by involving children, the threat of punishment is added $1 / 3$ (one third)". This provision is a preventive criminal policy to prevent adults from using children to carry out terrorist activities. The provisions in Article 16A become repressive when the criminal act of terrorism involving children occurs. Another policy used in providing protection for children from terrorism activities is the Regulation of the Minister of Women Empowerment and Child Protection Number 7 of 2019 on Guidelines for Child Protection from Radicalism and Criminal Acts of Terrorism (hereinafter referred to as Ministerial Regulation 2019). Considering the 2019 Ministerial Regulation, there are still parents and communities who teach radicalism and invite children to commit criminal acts of terrorism. Creating an atmosphere of terror or widespread fear and cause mass casualties that can interfere with children's development.

The Ministry of Women's Empowerment and Child Protection of the Republic of Indonesia, as summarized in the Explanation of the 2019 Ministerial Regulation, details the internal and external factors of children's involvement in terrorism networks. Internal factors, among others, are due to the influence of weakness in terms of religion, ignorance of nationalism, gender, age, intelligence, and children's emotional maturity. Several external factors also cause children involvement in

$46 \quad$ Arif Gosita, op.cit., p. 52. 
terrorism. Family, namely parents who involve children in the Terrorism network. Environment, namely friends involving them in the terrorism network. The media, especially the internet through radicalism websites with means of carrying out actions that lead to terrorism. Poverty, terrorists are generally from underprivileged families; they are promised and given salaries as well as life-long guarantees attracting them into the terrorism network. Education, generally, terrorists have low education, or they go to identified radicalized schools.

Prevention policies are prioritized to save children from exposure to terrorism and radicalism. Prevention activities aim to prevent children from being exposed to radicalism, hoping that children will not be part of the criminal act of terrorism. ${ }^{47}$ According to Article 5 paragraph (1) of the 2019 Ministerial Regulation, prevention is carried out by detecting and mapping the locations of children who are vulnerable to being affected by radicalism and engaging in criminal acts of terrorism. Such prevention is done by compiling as well as disseminating communication, information and education materials on child protection from radicalism and criminal acts of terrorism.

The rehabilitation process for children is an absolute key in preventing radicalization in prisons and supporting children who have been radicalized to quit and reintegrate into freedom. This is for both in a conflict area or the stability of the juvenile justice system. The children are rehabilitated by receiving constructive relationships based on trust in related parties, developing a sense of optimism about the children's future after being released, developing education, training and employment as well as relationships with family and friends (as long as it is in the best interests of the child). ${ }^{48}$ The 2019 Ministerial Regulation regulates several types of rehabilitation, namely medical, social, psychosocial and psychological rehabilitation. ${ }^{49}$

According to Hery Firmansyah in his research, the experiences of various countries in applying a concept that only prioritizes repressive actions by armed force or by strict law enforcement will not effectively stop terrorism. In addition to

$47 \quad$ Yudi Adnan and Rini Utami Ningsih, "Analisis Peraturan Menteri Pemberdayaan Perempuan dan Perlindungan Anak RI Nomor 7 Tahun 2019 tentang Pedoman Perlindungan Anak dari Radikalisme dan Tindak Pidana Terorisme", Jurnal Syntax Transformation, Vol. 1, No. 4, 2020, p. 73.

48 Sri Hahamu, "Pemenuhan Hak Anak sebagai Pelaku Tindak Pidana Terorisme", Lex Et Societatis, Vol. 8, No. 3, 2020, p. 36

49 According to the General Provisions in Article 1 of the 2019 Ministerial Regulation, Medical Rehabilitation is an integrated treatment to restore the physical condition of Child Victims, Child Perpetrators, and Children of Witnesses of Radicalism and Criminal Acts of Terrorism; Social Rehabilitation is a process of refunctionalization and development to enable Child Perpetrators, Child Victims, and Children Witnesses of Radicalism and Terrorism to be able to carry out their social functions fairly in community life; Psychosocial Rehabilitation is all forms of psychological and social services and assistance aimed at helping to alleviate, protect, and restore the physical, psychological, social and spiritual condition of the victim so that he is able to carry out his social function again properly; Psychological Rehabilitation is assistance provided by a psychologist to Child Victims or Child Witnesses who are suffering from trauma or other mental problems to restore the mental condition of Child Victims or Child Witnesses from the Crime of Terrorism. 
preventive and repressive steps, we must touch the roots of terrorism by resocializing and reintegrating terrorists into society. ${ }^{50}$ Malaysia, as a neighboring country to Indonesia, has experience in tackling criminal acts of terrorism. Malaysia is not isolated from the threats posed by terrorists, and the country could not rule out the possibility of "who and who" could be terrorist. ${ }^{51}$ In 2016, Malaysia experienced a terrorist attack carried out by ISIS at a nightclub near Kuala Lumpur. The grenade attack injured eight people. Since 2013, it is reported that Malaysia has arrested more than 400 ISIS supporters, including many individuals planning to travel to Syria and Iraq to attack in combat. ${ }^{52}$ Indonesia and Malaysia are the two countries of origin of the perpetrators who carry out acts of terrorism in those countries.

In providing protection for children from being involved in criminal acts of terrorism, Malaysia has several legal provisions, namely the Malaysia Act 769 Prevention of Terrorism Act 2015 and the Child Act 2001. Indonesia and Malaysia have the same provisions if children are involved in terrorism activities and become perpetrators. These two countries have legal provisions that specifically apply to children that are lighter than adults. Special procedures under the Children's Law change and set a precedent for any written law relating to arrest, detention and trial procedures. ${ }^{53}$ The criminal law policy should not only lead to a penal policy in punishing child offenders, but also prioritize a non-penal policy in the form of deradicalization. Rehabilitation and social reintegration of child perpetrators of terrorism must be carried out effectively so that children can be accepted back into their social environment when they are released from prison.

In countering terrorism, the Malaysian government involves all levels of society including military, police, border security, civil defense, medical and psychological preparation. The Malaysian government has a series of policies related to terrorism, such as the Internal Security Act (ISA), the Penal Code and the Regiment of Typical Motion under the British 22nd SAS training. ${ }^{54}$ Malaysia has a three-stage

\footnotetext{
50 Hery Firmansyah, "Upaya Penanggulangan Tindak Pidana Terorisme di Indonesia", Mimbar Hukum, Vol. 23, No. 2, 2011, p. 392.

51 Badrah Binti Yussof, "Terrorism - The Threat to Democracy, Peace and Security", https://www.parlimen.gov.my/images/webuser/TERRORISM\%20THE\%20THREAT\%20TO\%20DEMOCRACY.pdf, accessed on February 2021.

52 Overseas Security Advisory Council, "Malaysia 2020 Crime \& Safety Report", https://www.osac.gov/Content/Report/148f55ab-9111-47ef-99e4-1811a5d28a20, accessed on February 2021.

53 Muhammad Razmee Abd Raza, "The Juvenile Justice System in Malaysia", https://unafei.or.jp/publications/pdf/RS_No101/No101_14_IP_Malaysia.pdf, accessed on February 2021.

54 Arfin Sudirman and Deasy Silvya Sari, "Membangun Keamanan Regional di ASEAN dalam Menanggulangi Ancaman Terorisme", Jurnal Wacana Politik, Vol. 2, No. 1, 2017, p. 24.
} 
de-radicalization program. The first stage is that individuals are detained to give up religious bigotry. If it doesn't pose a security threat, it will be released. If it does, then it continues to the second stage, namely the Human Development Program with three bases: disciplinary development, personality enhancement and skills. The goal is to help individuals bridge the gap between themselves and society. The third stage is the post-detention period, during which detainees are required to maintain close contact with the police so that monitoring is more effective. The success rate of Malaysia's de-radicalization program even reached 97 percent, and it is said that it will continue to increase every year. ${ }^{55}$

It is important to note for every country to develop mechanisms and protection for children whose parents become terrorists. The children whose parents are arrested as terrorist perpetrators and even die in arrest, both inside and outside the country, must get attention. First, the children will lose their parents to provide for them. Second, the children will lose the place of care. The children must be saved from wrong parenting. If the government does nothing, it is not impossible for these children to be raised by terrorist networks. Consequently, when they grow up, they have a strong tendency to become terrorists.

\section{Conclusion}

The involvement of children as perpetrators of terrorism places them as victims of mistreatment of childcare and social environment. They live in a cycle of violence in which their parents radicalize them. Terrorism behavior is not a genetic factor, it is a social learning from the environment. Children from terrorist families tend to get stigmatized, labeled, and bullied by the social environment. This condition can bring them closer to an environment that sees violence as a common thing. The criminal policy in tackling the involvement of children in terrorism activities is carried out by means of a penalty policy with one-third penalty addition to bring down every person who commits a criminal act of terrorism by involving a child. The non-penal policy is carried out to prevent the involvement of children in terrorism activities. Effective rehabilitation needs to be carried out for children who have been exposed to the doctrine of terrorism by separating them from terrorism care and networks.

\section{References}

\section{Books}

Abdul Wahid (et.al.), Kejahatan Terorisme Perspektif Agama, HAM dan Hukum, Refika Aditama, Bandung, 2004. Arif Gosita, Masalah Perlindungan Anak, Akademi Presindo, Jakarta, 2001.

\footnotetext{
55 Aditya Putra and Diana Lukitasari, "Perbandingan Pengaturan Tindak Pidana Terorisme di Indonesia dan Malaysia", Jurnal Hukum Pidana dan Penanggulangan Kejahatan, Vol. 8, No. 1, 2019, p. 10.
} 
Barda Nawawi Arief, Kebijakan Legislatif dalam Penanggulangan Kejahatan dengan Pidana Penjara, Universitas Diponegoro, Semarang, 1994.

Dikdik M Arief Mansur and Elisatris Gultom, Cyber Law Aspek Hukum Teknologi Informasi, Refika Aditama, Bandung, 2005.

Gallimore, Timothy, Unresolved Trauma: Fuel for the Cycle of Violence and Terrorism, Greenwood Publishing Group, Washington, DC, 2004.

Kartini Kartono, Gangguan-gangguan Psikhis, Sinar Baru, Bandung, 1981.

Khariroh Maknunah, Penanganan Anak dalam Tindak Pidana Terorisme, Csave, Jakarta, 2016.

M. Nasir Djamil, Anak Bukan untuk Dihukum, Sinar Grafika, Jakarta, 2013.

Maidin Gultom, Perlindungan Hukum terhadap Anak dalam Sistem Peradilan Pidana Anak Indonesia, Rafika Aditama, Bandung, 2014.

Marlina, Peradilan, Pidana Anak di Indonesia, Refika Aditama, Bandung, 2012.

Mohammad Ali, Psikologi Remaja, Bumi Askara, Jakarta, 2012.

Soerjono Soekanto, Pokok-pokok Sosiologi Hukum, PT Raja Grafindo Persada, Jakarta, 2009.

Sutton, Adam (et.al.), Crime Prevention Principles, Perspectives, and Practices, Cambridge University Press, New York, 2008.

The Child Rights International Network, Caught in the Crossfire? An International Survey of Anti-Terrorism Legislation and Its Impact on Children, CRIN Press, London, 2018.

Widom, Cathy S. and Maxfield, Michael G, An Update on the "Cycle of Violence", U.S. Department of Justice, Washington, 2011.

\section{Other Documents}

Aditya Putra and Diana Lukitasari, "Perbandingan Pengaturan Tindak Pidana Terorisme di Indonesia dan Malaysia", Jurnal Hukum Pidana dan Penanggulangan Kejahatan, Vol. 8, No. 1, 2019.

Adrah Binti Yussof, "Terrorism - The Threat to Democracy, Peace and Security", https://www.parlimen.gov.my/images/webuser/TERRORISM\%20THE\%20THREAT\%20TO\%20DEMOCRACY.pdf.

Agus Sugiarto, "Tinjauan Yuridis Anak sebagai Pelaku Tindak Pidana Terorisme tentang Sistem Peradilan Pidana Anak", Jurnal Syntax Transformation, Vol. 1, No. 9, 2020.

Ahmad Mahyani, "Perlindungan Hukum Anak sebagai Pelaku Terorisme", Jurnal Hukum Magnum Opus, Vol. 2, No. 1, 2019. 
Antara, "Kesaksian Tragedi Bom Gereja Katolik Santa Maria Tak Bercela", https://www.cnnindonesia.com/nasional/20180514085029-20297935/kesaksian-tragedi-bom-gereja-katolik-santa-maria-tak-bercela.

Arfin Sudirman and Deasy Silvya Sari, "Membangun Keamanan Regional di ASEAN dalam Menanggulangi Ancaman Terorisme", Jurnal Wacana Politik, Vol. 2, No. 1, 2017.

Josua Hamonangan Bangun, "Internalisasi Kesadaran Berbangsa Bernegara Anak Teroris", JUSTITIA: Jurnal IImu Hukum dan Humaniora, Vol. 7, No. 3, 2020.

Deny Guntara, "Tinjauan Kriminologi terhadap Pelaku Tindak Pidana Terorisme di Indonesia dalam Perspektif Teori Differential Association", Justisi Jurnal IImu Hukum, Vol. 3, No. 1, 2018.

Fox, Bryanna, "It's Nature and Nurture: Integrating Biology and Genetics into the Social Learning Theory of Criminal Behaviour", Journal of Criminal Justice, Vol. 49, No. 1, 2017.

Hery Firmansyah, "Upaya Penanggulangan Tindak Pidana Terorisme di Indonesia", Mimbar Hukum, Vol. 23, No. 2, 2011.

Irfan Kamil, "Kementerian PPPA Sebut Media Sosial Kini Dipakai untuk Rekrut Anak dalam Aksi Terorisme", https://nasional.kompas.com/read/2020/07/08/18160401/kementerian-pppasebut-media-sosial-kini-dipakai-untuk-rekrut-anak-dalam?page=all.

Jobpie Sugiharto, "Jumlah Perempuan Terlibat Terorisme Meningkat, Lihat Angkanya", https://nasional.tempo.co/read/1276689/jumlah-perempuanterlibat-terorisme-meningkat-lihat-angkanya/full\&view=ok.

Kautsar Widya Prabowo, "1.800 Anak Pelaku Terorisme Tidak Terjamah Pemerintah", https://www.medcom.id/nasional/hukum/IKY6ZoWN-1-800anak-pelaku-terorisme-tidak-terjamah-pemerintah.

Laode Arham, "Budaya Penjara, Subkultur Terorisme dan Radikalisasi: Perspektif Kriminologi Budaya", Journal of Terrorism Studies, Vol. 2, No. 4, 2021.

Markus H Simarmata, "Pentingnya Prinsip-Prinsip Hukum Humaniter dalam Undang-Undang Tindak Pidana Terorisme", Jurnal Legislasi Indonesia, Vol. 15, No. 2, 2018.

Muhammad Razmee Abd Raza, "The Juvenile Justice System in Malaysia", https://unafei.or.jp/publications/pdf/RS_No101/No101_14_IP_Malaysia.pdf.

Overseas Security Advisory Council, "Malaysia 2020 Crime \& Safety Report", https://www.osac.gov/Content/Report/148f55ab-9111-47ef-99e41811a5d28a20.

Riad Tia Wardana and Dahlan Ali, "Upaya Pencegahan Tindak Pidana Terorisme oleh Direktorat Intelijen Keamanan (Suatu Penelitian di Kepolisian Daerah Aceh)", Jurnal Ilmiah Mahasiswa Bidang Hukum Pidana, Vol. 3, No. 3, 2019.

Rindha Widyaningsih, Sumiyem Sumiyem, and Kuntarto Kuntarto, "Kerentanan Radikalisme Agama di Kalangan Anak Muda", Prosiding, Vol. 7, No. 1, 2017. 
Rini, Dian Eko, and Teguh Kurniawan, "Deradikalisasi Teroris melalui Lapas Supermaksimum Security dari Perspektif Implementasi Kebijakan", Publikauma: Jurnal Administrasi Publik Universitas Medan Area, Vol. 7, No. 2, 2019.

Runturambi, Arthur Josias Simon, and Sidratahta Mukhtar, "Strategi Pencegahan Serangan Teroris di Indonesia Menggunakan Weapons Mass Destruction (WMD) oleh POLRI, BNPT, BAPETEN, TNI, BNPB dan KEMENPERIN", Journal of Terrorism Studies, Vol. 2, No. 1, 2020.

Saifudin Asrori, "Prisonisasi dan Penyebaran Ideologi Radikal di Lembaga Pemasyarakat", Mimbar Agama Budaya, Vol. 36, No. 1, 2019.

Saraswati and Elsafira Maghfiroti Resyanta, "Pemprofilan Pelaku Teroris Anak", Etnoreflika: Jurnal Sosial dan Budaya, Vol. 9, No. 2, 2020.

Sri Hahamu, "Pemenuhan Hak Anak sebagai Pelaku Tindak Pidana Terorisme", Lex Et Societatis, Vol. 8, No. 3, 2020.

United Nations Interregional Crime and Justice Research Institute, "Promoting Juvenile Justice Standards to Prevent the Recruitment by Violent Extremist Organizations", http://www.unicri.it/topics/counter_terrorism/juvenile_diversion.

United Nations Office on Drugs and Crime, "Global Programme to End Violence Against Children," https://www.unodc.org/unodc/en/justice-and-prisonreform/global-programme-to-end-violence-against-children_programmedetails.html.

Uswatun Hasanah and Santoso Tri Raharjo, "Penanganan Kekerasan Anak Berbasis Masyarakat", Share: Social Work Journal, Vol. 6, No. 1, 2016.

Yohanes Servasius Lon and Fransiska Widyawati, "Lingkaran Kekerasan terhadap Anak dalam Masyarakat Manggarai", Jurnal Pendidikan dan Kebudayaan Missio, Vol. 9, No. 1, 2017.

Yudi Adnan and Rini Utami Ningsih, "Analisis Peraturan Menteri Pemberdayaan Perempuan dan Perlindungan Anak RI Nomor 7 Tahun 2019 tentang Pedoman Perlindungan Anak dari Radikalisme dan Tindak Pidana Terorisme", Jurnal Syntax Transformation, Vol. 1, No. 4, 2020.

\section{Legal Documents}

Convention on the Rights of the Child 1989.

The Law of the Republic of Indonesia Number 11 of 2012 on the Juvenile Criminal Justice System [Undang-Undang Republik Indonesia Nomor 11 Tahun 2012 tentang Sistem Peradilan Anak].

The Law of the Republic of Indonesia Number 5 of 2018 on the Amendments to Law Number 15 of 2003 on Stipulation of Government Regulations in Lieu of 
Law Number 1 of 2002 on the Eradication of Criminal Acts of Terrorism into Law [Undang-Undang Republik Indonesia Nomor 5 Tahun 2018 tentang Perubahan Atas Undang-Undang Nomor 15 Tahun 2003 tentang Penetapan Peraturan Pemerintah Pengganti Undang-Undang Nomor 1 Tahun 2002 tentang Pemberantasan Tindak Pidana Terorisme Menjadi Undang-Undang].

Regulation of the Minister of Women Empowerment and Child Protection Number 7 of 2019 on Guidelines for Child Protection from Radicalism and Criminal Acts of Terrorism [Peraturan Menteri Pemberdayaan Perempuan dan Perlindungan Anak Nomor 7 Tahun 2019 tentang Pedoman Perlindungan Anak dari Radikalisme dan Tindak Pidana Terorisme]. 